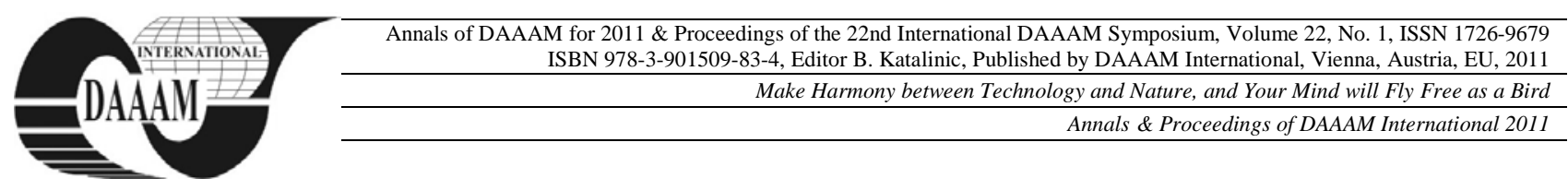

\title{
OVERVIEW OF CRUCIAL VARIABLES FOR M\&A SUCCESS
}

\author{
FILIPOVIC, D[avor]; SAPUNAR, I[gor] \& SAPUNAR, G[oran]
}

\begin{abstract}
Despite the increasing popularity of mergers and acquisitions, it has been reported that, more than two-thirds of large merger deals fail to create value for shareholders. Therefore, the main aim of this paper is to present the importance of crucial organizational variables, especially corporate culture
\end{abstract}

Key words: mergers and acquisitions, strategic alliances, corporate culture, organizational variables

\section{INTRODUCTION}

Mergers and acquisitions, as a part of the growth strategy, but also as a research field of numerous scientists and consultants, represent prominent phenomenon of developed capitalist world since the end of $20^{\text {th }}$ century. Growth of the company trough M\&A provides access to new markets and resources, and success or failure of M\&A is of great importance not only for companies included that in that process, but also for all participants of that process, and for the whole economy.

Respecting the fact that vast number of M\&As do not achieve planed synergies and results, this paper focuses on the importance of corporate culture which can be seen as a crucial variable for M\&A success. After pointing out characteristics of growth strategy implementation, crucial variables for M\&A success are presented with special focus on corporate culture.

\section{CHARACTERISTICS OF GROWTH STRATEGY IMPLEMENTATION}

In turbulent business environment of $21^{\text {st }}$ century organizations are forced to use different growth strategies in order to successfully position with respect to competition and to preserve and increase their profit margins. Growth strategy is part of the corporate strategy which emphasizes corporation as a whole and provides answers regarding business scope of the corporation and recourse allocation (Tipurić, 2005). Growth strategies are concerned with increasing the size and viability of the business over time. A successful growth strategy will allow entrepreneurs to increase its customer base, market segments, geographical scope, and/or product lines, which should lead to revenue growth. Permanent growth enables them to build and sustain their competitive market position (Filipović \& Grgić, 2011).

Modern business world is cognizant with three ways of implementing growth strategies including: internal or organic growth, growth through mergers and acquisitions, and growth through strategic alliances (Filipović et al., 2011). Company pursues internal growth by relying on its resources, and also through increase of products and services sold on existing markets, independent development of new products and penetration to new markets (Tipurić, 2005). Considering the fact that internal growth represents the slowest way to grow and considering that companies cannot accomplish planned growth only by relying on its own resources, companies often to expand business through mergers and acquisitions or through strategic alliances (Tipurić \& Markulin, 2002).
Acquisition refers to purchase of controlling interest of company "A" in company "B". Controlling interest presents purchase of more than $50 \%$ voting shares of company "B". In most cases, payment instrument of controlling interest is money, shares of company "A" or combination of money and shares. Acquirer is usually bigger than target company (Agwin, 2007). Target company becomes an integral part of a company that is bigger, has bigger market share and occasionally takes its name. Sometimes target company keeps its own name while operating within the new group but loses operational autonomy and instead of its previous strategy uses the strategy of acquirer company (Tipurić \& Markulin, 2002). According to the Companies Act regarding acquisition of one or more companies from another company, one or more company can transfer all its assets (assets of target) to another company (Barbić, 2007).

The most prevalent forms of alternative growth strategies include strategic alliances. The strategic alliance is a coalition of companies that aims to strengthen its market position and improve operating results (Ireland et al., 2002). This is an agreement between two or more companies which are related to common business and/or distribution of resources to achieve mutual benefit (Drago, 1997). Alliance is an inter organizational form in which they engage special knowledge, skills and/or resources of co-operating companies in order to achieve the common and individual goals, specific to each company. This is an explicit long-term contractual arrangement for the exchange and/or a combination of some (but not all) enterprise resources with one or more other companies (Burger et al., 1993). Therefore, the strategic alliance is not a precise category that is easy to define, but strategic alliances are not all the possible connections between companies (Tipurić \& Markulin, 2002). Through the alliance companies share the tangible and intangible resources, while minimizing transaction costs and reducing the technological and market uncertainties, those are just some of the modalities how to improve market position and operating results of the allies through the alliances (Hitt et al., 2000).

\section{CRUTIAL VARIABLES FORM \& A SUCCESS}

Despite the increasing popularity of mergers and acquisitions, it has been reported that, more than two-thirds of large merger deals fail to create value for shareholders (Cingula et al., 2010).

The "2 $+2=5$ " effect between two business units that will increase competitive advantage by achieving synergies and improving overall performance is usually primary purpose of merging and acquiring new firms (Appelbaum et al., 2000). Since synergies are rarely realized M\&A literature indicates that there has been intense interest in examining human and cultural aspects of M\&As as traditional explanations have not adequately explained the high rate of M\&A failures. The literature drawn on cultural differences is derived from the organizational behavior school of thought. The effects of culture can take place in the early stages of the acquisition process but are especially crucial in the post-acquisition 
management period (Quah \& Young, 2005). Systematic research indicates that the greatest danger for value creation that should come out M\&A comes after two companies try to integrate operations. Fralick and Bolster point out that culture can be a break or make factor in merger equation. Incompatible culture is major reason why financial benefits anticipated from mergers are often unrealized for Carwright and Cooper (Carwright \& Cooper, 1993). Weber emphasizes that magnitude of cultural differences can effectively impede successful integration during M\&A resulting in poor performance (Weber, 1996). It is widely acknowledged that cultural compatibility alone is not guarantee to M\&A success, but is not wrong to say that cultural heterogeneity creates tensions and affects financial and managerial performance (Brock et al., 2005).

Human resources tend to react negatively after being acquired. Mergers and acquisitions are major change in lives of corporations and those employed by them. The changes occasioned by acquisitions are often wide ranging. They may change strategies, operations, cultures, the relationship between staff and managers, team relationships, power structures, incentive structures and job prospects. M\&A may require individuals to change their life styles, behavior, personal beliefs and value systems. Acquisitions create anxiety, fear and often are traumatic events for those who might lose their jobs (Reilly et al., 1993). However, the strength duration and dysfunctional effects of such reaction vary between different M\&As. This negative employee reaction is often referred as a "cultural clash" (Buono \& Bowditch, 1989). Cultural clash has been shown to have dysfunctional consequences such as lower commitment and cooperation between acquired employees (Bouno el al., 1985), greater turnover among acquired employees (Lubatkin et al., 1999), a decline in shareholder value of the buying firm, and deterioration of operating performance of the acquired firm (Chatterjee et al., 1992). According to Carwright and Cooper, and Carey certain culture types can be disastrous and can lead to cultural ambiguity, confusion and hopelessness. Therefore, the management of the human factor in M\&A has been recognized as an important source of success by number of researchers. Lodorfos and Boateng conducted a research in chemical industry in period 1999-2004, and had 32 interviews with senior managers of 16 M\&A deals. Their study identifies culture differences between merging firms as the key element affecting M\&A success. Almost all interviewers agreed that M\&As often failed to achieve expected outcomes of the merger because of lack of cultural fit or incompatible cultures (Lodorfos \& Boateng, 2006).

\section{CONCLUSION}

Increased external pressures are reason why companies have to search outside their internal boundaries to build or reinforce their competitive capabilities. Since mergers and acquisitions are popular choice for companies' growth and expansion, and also a mean for creating better market position companies will have to engage in these transaction more often if they want to be competitive. Therefore it is extremely important that they peruse growth strategies but also take into consideration the importance of organizational variables for M\&A success. Research evidence emphasizes the importance of corporate culture and human factors in M\&A success and one of the crucial tasks for M\&A practitioners is to assess culture compatibility before closing the deal.

\section{REFERENCES}

Agwin, D. (2007). Mergers and Acquisitions, Blackwell Publishing, ISBN: 9781405122399, Malden

Appelbaum, S. H. (2000). Anatomy of a merger: Behavior of organizational factors and processes throughout the pre- during-post-stages (part 1). Management Decision, Vol. 38, No. 9, pp. 649-661, ISSN: 0025-1747

Barbić, J. (2007). Pravo društava: društva kapitala, knjiga druga, Organizator, ISBN: 9789537585273, Zagreb

Brock, D. M. (2005). Multinational acquisition integration: the role of national culture in creating synergies. International Business Review, Vol. 14, No. 3, pp. 269-288, ISSN: 09695931

Buono, A. F. \& Bowditch, J. L. (1989). The Human Side of Mergers and Acquisitions: Managing Collisions Between People and Organizations, Josey-Bass, ISBN: 1555421350, San Francisco

Burger, W. P.; Hill, C. W. L. \& Kim, W. C. (1993). A Theory of Global Strategic Alliances: the Case of Global Auto Industry. Strategic Management Journal, Vol. 14, No. 6, pp. 419-432, ISSN: 1097-0266

Cartwright, S. \& Cooper, C. L. (1993) The psychological impact of merger and acquisition on the individual: a study of building society managers. Human Relations, Vol. 46, pp. 327-347, ISSN: 1741-282X

Chatterjee, S.; Lubatkin, M.; Schweiger, D. \& Weber, Y. (1992). Cultural differences and shareholder value in related mergers: linking equity and human capital. Strategic Management Journal, Vol. 13, pp. 319-334, ISSN: 10970266

Cingula, M.; Filipović, D. \& Podrug, N. (2010). Mergers and acquisitions in Croatia and Lithuania. Journal of International Scientific Publication: Economy \& Business, Vol. 4, No. 2, pp. 349-364, ISSN: 1313-2555

Drago, W. A. (1997). When Strategic Alliance Make Sense. Industrial Management \& Data Systems, Vol. 97, No. 2, pp. 53-57, ISSN: 0263-5577

Filipović, D. \& Grgić, K. (2011). Entrepreneurial growth strategies: Comparison of Croatia and Slovenia, Proceedings of International Conference on Entrepreneurship, Education, Innovations, Maribor, Slovenia, June 30 - July 01, pp. 63-76, ISBN: 978-9616802-05-5

Filipović, D.; Podrug, N. \& Bujanović, H. (2011). Mergers and acquisition: the case of Croatia, Proceedings of the 5th International Scientific Conference "Entrepreneurship and Macroeconomic Management: Reflections on the World in Turmoil", Pula, Croatia, March 24-26.

Hitt, M. A.; Dacin, M. T.; Levitas, E.; Arregle, J. \& Borza, A. (2000). Partner selection in emerging and developed market contexts: resource based and organizational learning perspective. Academy of Management Journal, Vol. 43, No. 3, pp. 449-467, ISSN: 0001-4273

Ireland, R. D.; Hitt, M. A. \& Vaidyanath, D. (2002). Alliance management as a source of competitive advantage. Journal of management, Vol. 28, No. 3, pp. 413-446, ISSN: 15571211

Lodorfos G. \& Boateng A. (2006). The role of culture in the merger and acquisition process: Evidence from European chemical industry. Management Decision, Vol. 44, No. 10, pp. 1405-1421, ISSN: 0025-1747

Lubatkin, M. (1983). Mergers and the performance of the acquiring firm. Academy of Management Review, Vol. 8, No. 2, pp. 218-225, ISSN: 1930-3807

Quah P. \& Young S. (2005). Post-acquisition Management: A Phases Approach for Cross-border M\&As. European Management Journal, Vol. 23, No. 1, pp. 65-75, ISSN: 0263-2373

Reilly A. H.; Brett J. M. \& Stroh L. K. (1993). The impact of corporate turbulence on managers' attitudes. Strategic Management Journal, Vol. 14, Special Issue, pp. 167-179, ISSN: 1097-0266

Tipurić, D. \& Markulin G. (2002). Strateški savezi: suradnjom poduzeća do konkurentske prednosti, Sinergija, ISBN: 9536895-09-9, Zagreb 